\title{
DARK-GROUND ILLUMINATION OF UNSTAINED SMEARS AND TISSUE SECTIONS FOR THE DIAGNOSIS OF TREPONEMA PALLIDUM*
}

BY

\author{
WALDEMAR E. COUTTS, EDNA SILVA-INZUNZA, \\ and GUILLERMO MORALES-SILVA $\dagger$ \\ Social Hygiene Department, Public Health Service, Chile
}

Unstained smears of secretions and sections of tissues can be investigated under dark-ground illumination for the presence of Treponema pallidum.
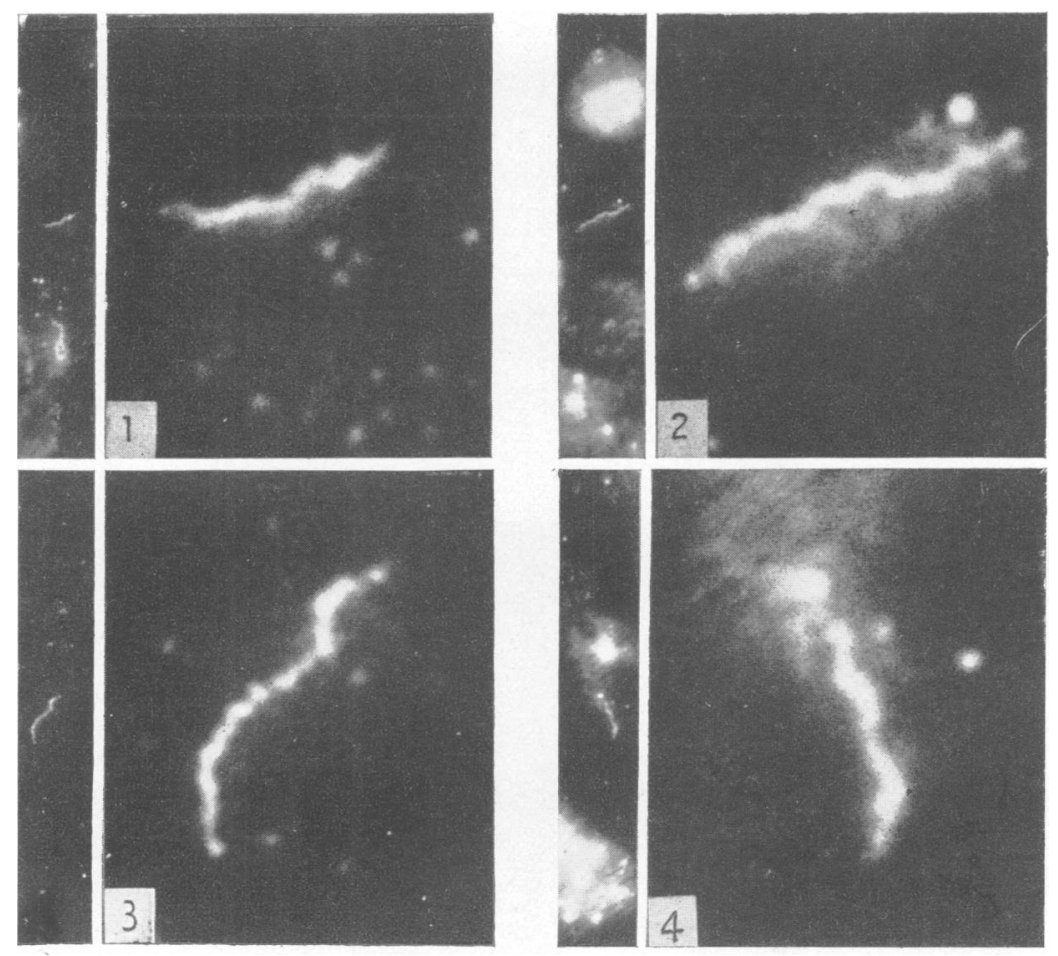

FIG. 1.-Treponema pallidum. Original approx. $\times 360$. Enlargement $6 \frac{1}{2}$ diameters.

\section{Technique}

A thin smear of material is spread on a glass slide, fixed in 10 per cent. formalin solution for 2 minutes,

* Received for publication December 17, 1951,

+ With the cooperation of Mr. José Valladares-Prieto, photographic technician of Chile Public Heaith Service (Department of Sanitary Education) washed in distilled water, and dried by blotting on filter paper. Room temperature is sufficient for drying and fixing the smear if it is to be examined within $48 \mathrm{hrs}$. Tissues

should be fixed in 10 per cent. formalin, imbedded in paraffin, cut in very thin sections, spread on a glass slide, and prepared as for staining, but not mounted. Smears and sections can be observed under simple immersion-oil only on the paraboloid condenser-or under double immersion. With the latter method, a cover glass is laid over the smear or section and a drop 

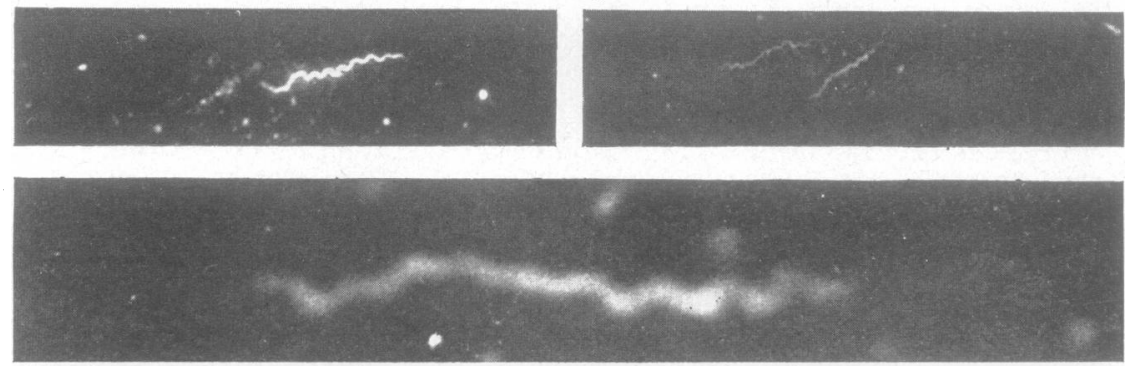

FIG. 2.-Treponema pallidum. Original approx. $\times 900$. Double immersion. Enlargement $6 \frac{1}{2}$ diameters.

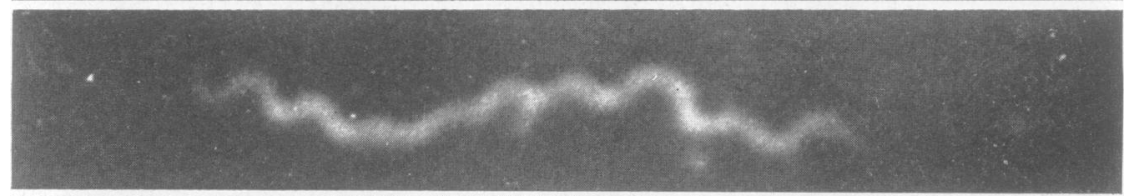

of cedar-wood oil is placed on its upper surface. After observation the cover glass can be removed without damaging the preparation, which can be kept and observed as often as desired.

\section{Commentary}

T. pallida in fixed, unstained smears or sections appear motionless and brilliantly illuminated, and preserve all their currently accepted morphological characteristics as shown under the electron micro-
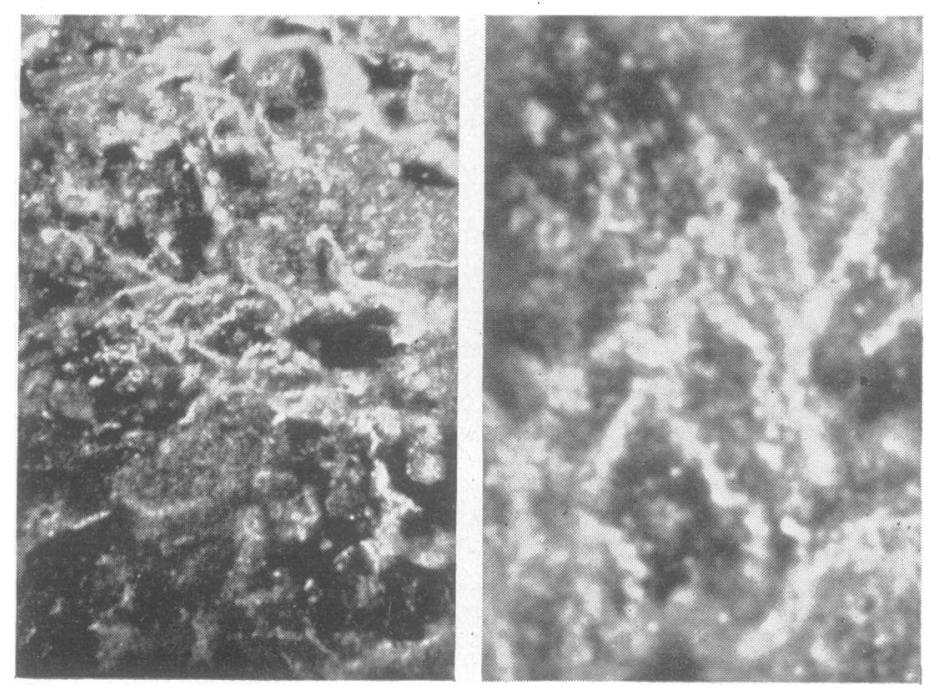

FIG. 3.-Unstained section of syphilitic neonatal liver showing large numbers of Treponema pallidum. Original double immersion. scope or when observed by pilase-contrast micïcscopy. In the photomicrographs accompanying this communication such structures as buds and cysts can be observed (Figs 1-3).

The technique here described has several advantages ; in particular it allows the examination of slides containing suspected material, no matter how far the patient may be from the laboratory and up to 3 months after the collection of the specimen. We believe that this may be of great help in antisyphilitic or antitreponemal campaigns (Coutts and others, 1951,) as slides can be sent for diagnosis to a base laboratory. For the diagnosis of open lesions, the observation of fixed smears is much easier than the examination of fresh preparations, for, instead of following the micro-organisms about and constantly moving the preparation to keep them in the field, the slide can be examined at leisure.

From the standpoint of pathology, the observation of thin sections of suspected tissues under dark-ground illumination is also of importance because staining difficulties are obviated. This belief is confirmed by the accompanying microphotographs.

\section{Summary}

The epidemiological and economic advantages of dark-ground illumina- 
tion of fixed unstained smears or tissue sections of suspected syphilitic material are numerous, especially in antisyphilitic campaigns carried out in underdeveloped countries or large sparsely populated territories.

From a purely scientific point of view, the morphology and life cycle of treponemata can also be advantageously studied by this simple technique.

\section{REFERENCE}

Coutts, W. E., Silva-Inzunza, E., and Valladares-Prieto, J. (1951). " Contribucion al estudio de caracteristicas morfologicas de algunos microorganismos espiroidales -Treponemas y Espirilos - en imagenes obtenidas de preparaciones fijas-tenidas o no tenidas-observadas bajo campo obscuro", Rev. chil. Urol., 14, 83.

\section{JOURNAL OF VENEREAL DISEASES INFORMATION}

Back numbers of this journal are required for the Library of the Medical School of Leeds University. Offers should be addressed to Dr. G. O. Horne, Department for Venereal Diseases, General Infirmary, Leeds, Yorks. 